Utah State University

DigitalCommons@USU

T.W. "Doc" Daniel Experimental Forest

Quinney Natural Resources Research Library,

S.J. and Jessie E.

$9-2012$

\title{
Estimation of Soil Clay Content from Hygroscopic Water Content Measurements
}

\author{
Mark N. Wuddivira \\ David A. Robinson \\ Imma Lebron \\ Laetitia Brechet \\ Melissa Atwell \\ Sunshine De Caires
}

See next page for additional authors

Follow this and additional works at: https://digitalcommons.usu.edu/docdan

\section{Recommended Citation}

M.N. Wuddivira et al. 2012. Estimation of soil clay content from hygroscopic water content measurements. Soil Science Society of America Journal. 76 (5): 1529-1535

This Article is brought to you for free and open access by the Quinney Natural Resources Research Library, S.J. and Jessie E. at DigitalCommons@USU. It has been accepted for inclusion in T.W. "Doc" Daniel Experimental Forest by an authorized administrator of DigitalCommons@USU.

For more information, please contact

digitalcommons@usu.edu.

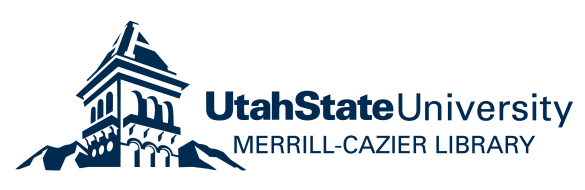




\section{Authors}

Mark N. Wuddivira, David A. Robinson, Imma Lebron, Laetitia Brechet, Melissa Atwell, Sunshine De Caires, Michael Oatham, Scott B. Jones, Hiruy Abdu, Aditya K. Verma, and Markus Tuller 


\section{Estimation of Soil Clay Content from Hygroscopic Water Content Measurements}

\author{
Mark N. Wuddivira* \\ Dep. of Food Production \\ the Univ. of the West Indies \\ St. Augustine, Trinidad and Tobago \\ David A. Robinson \\ Inma Lebron \\ Centre for Ecology and Hydrology \\ Environment Centre Wales \\ Deiniol Road \\ Bangor, Gwynedd, UK

\section{Laëtitia Bréchet \\ Soil Team \\ Environmental Dynamics and Spatial Organizations UMR INRA-AgroParisTech Environnement et Grandes Cultures Thiverval- Grignon, France and \\ Dep. of Life Sciences the Univ. of the West Indies St Augustine \\ Trinidad and Tobago}

\section{Melissa Atwell}

Sunshine De Caires

Dep. of Food Production the Univ. of the West Indies St. Augustine, Trinidad and Tobago

\section{Michael Oatham}

Dep. of Life Sciences the Univ. of the West Indies St Augustine, Trinidad and Tobago

\section{Scott B. Jones}

Hiruy Abdu

Dep. of Plants Soils and Climate

Utah State Univ.

Logan, UT 84322

\section{Aditya K. Verma}

Markus Tuller

Dep. of Soil, Water and Environmental Science,

The Univ. of Arizona

Tucson, AZ 85721
Soil texture and the soil water characteristic are key properties used to estimate flow and transport parameters. Determination of clay content is therefore critical for understanding of plot-scale soil heterogeneity. With increasing interest in proximal soil sensing, there is the need to relate obtained signals to soil properties of interest. Inference of soil texture, especially clay mineral content, from instrument response from electromagnetic induction and radiometric methods is of substantial interest. However, the cost of soil sampling and analysis required to link proximal measurements and soil properties, for example, clay mineral content, can sometimes outweigh the benefits of using a fast proximal technique. In this paper, we propose that determination of a soil's hygroscopic water content at $50 \%$ atmospheric relative humidity $\left(\mathrm{RH}^{50}\right)$, which is time and cost efficient, and particularly suitable for developing countries, can act as a useful surrogate for clay content in interpreting soil spatial patterns based on proximal signals. We used standard clays such as kaolinite, illite, and montmorillonite to determine the water release characteristic as a function of hygroscopic water content. We also determined clay content of soils from temperate (Arizona, United States) and tropical (Trinidad) regions using the hydrometer method and hygroscopic water content for soils equilibrated at $\mathbf{R H}^{50}$. We found linear dependence of clay percentage and $\mathrm{RH}^{50}$ for a range of soil mineralogies. Hygroscopic water measurements offer an inexpensive and simple way to estimate site-specific clay mineral content that in turn can be used to interpret geophysical signal data in reconnaissance surveys.

Abbreviations: EMI, electromagnetic induction; $\mathrm{RH}$, relative humidity.

S oil texture (percentage of sand, silt, and clay) is a fundamental parameter in soil science (Gee and Bauder, 1986) and a major component of the soil natural capital (Robinson et al., 2009a). Texture is widely used in agriculture and engineering as well as in basic research to estimate for example water release curves in flow and transport modeling (Schaap et al., 2001). Soil texture, especially clay content, controls magnitude and rates of many physical, chemical and hydrological processes in soils. Important soil phenomena such as nutrient storage, nutrient availability, water retention, and stability of aggregates may vary across the field in response to the spatial variability of clay percentage. Soil moisture which is the major control for rainfall-runoff response in a watershed (Robinson et al., 2008a) has been directly linked to clay variability (Crave and Gascuel-Odoux, 1997). Net nitrification and $\mathrm{CO}_{2}$ release has been shown to depend on water content and clay content (Schjonning et al., 2003). Knowledge of texture, especially the spatial distribution of clay content, is therefore important for a range of ecosystem services, including provisioning through agricultural production and regulating of the hydrological cycle through filtering and buffering. A growing challenge in soil science is to map soil natural capital, of which texture is a component, in a way that allows us to scale from the soil profile to field to regions.

Soil Sci. Soc. Am. J. 76:1529-1535

doi:10.2136/sssaj2012.0034

Received 30 Jan. 2012.

*Corresponding author (wuravnakka@yahoo.com).

(C) Soil Science Society of America, 5585 Guilford Rd., Madison WI 53711 USA

All rights reserved. No part of this periodical may be reproduced or transmitted in any form or by

any means, electronic or mechanical, including photocopying, recording, or any information storage and retrieval system, without permission in writing from the publisher. Permission for printing and for reprinting the material contained herein has been obtained by the publisher. 
Proximal sensing techniques, especially geophysical sensors that infer spatial textural information from instrument response to ions adsorbed on clay minerals (Robinson et al., 2008b), provide an invaluable means for filling the 'intermediate' scale data gap. Electromagnetic induction (Doolittle et al., 1994; Triantafilis et al., 2001; Triantafilis and Lesch, 2005), resistivity (Samouelian et al., 2005), induced polarization (Slater et al., 2006), and radiometrics (Rawlins et al., 2007) are techniques progressively used to determine soil properties or spatial patterns related to texture, inferred from mineralogy and cation binding. In case of electrical methods, cations adsorbed to 2:1 clay minerals can be used to interpret, or determine, the spatial pattern of clay percentage in non-saline soils (Triantafilis et al., 2001; Triantafilis and Lesch, 2005; Sudduth et al., 2005; Harvey and Morgan, 2009). This method is limited to clays that adsorb cations to counter balance negative charge sites and is less likely to work for clay minerals with low surface areas, for example, kaolinites. In case of radiometrics, many clay minerals, for example, hydrous micas and illites, can be detected through their potassium isotope signal (Taylor et al., 2002). Knowledge of clay content is therefore critical for the signal interpretation of proximal sensing instruments.

Direct, grid-like soil sampling for identifying spatial textural patterns has several limitations among which the need for high-intensity sampling and associated costs for analyses are the most constraining ones. In addition, minimizing soil disturbance, that is, not filling the landscape with holes is vital for many hydrological process studies. In many cases, an understanding of soil spatial patterns, and delimiting of hydrological functional units, is more important than the exact knowledge of soil properties (Grayson and Blöschl, 2000). The costs for independently measuring soil properties for calibration of proximal signals have always been an issue, such that Lesch et al. (1995a, 1995b) developed efficient sampling methods for interpreting EMI signal response from directed soil sampling. Even with approaches like theirs, the particle size analysis presents a substantial cost for calibration, especially if multiple fields are sampled.

In this paper we propose that under many circumstances, a site-specific calibration between clay percentage and hygroscopic water content could be used to greatly reduce the number of particle size analyses that might be done for a proximal sensing site calibration. Estimating clay percentage from hygroscopic water content presents a cost efficient, simple, and reliable surrogate for correlating proximal signal response to soil clay content; although, the paper does not specifically explore EMI calibration. Our major goal is to investigate if simple, cost, and time efficient hygroscopic water content measurements can be used to estimate clay contents for soils with varying mineralogies.

In soils, soil solution electrical conductivity $\left(\mathrm{EC}_{\mathrm{e}}\right)$, volumetric soil water $\left(\theta_{\mathrm{v}}\right)$, and clay contents are the major factors influencing bulk soil electrical conductivity (EC; ; Friedman, 2005) and EMI signal response. In the case of radiometrics, clay content and, to a lesser extent, soil moisture are the driving factors. The intimate relationship between soil clay content and hygroscopic water content is well established (Briggs and Shantz, 1912; Banin and Amiel, 1970; Petersen et al., 1996) but not widely exploited. It was proposed as a method for determining soil surface area but largely abandoned because water tends to cluster on charged clay mineral surfaces not forming a monolayer like ethylene glycol monomethyl ether, which has a lower dielectric constant, or non-polar nitrogen (Quirk and Murray, 1999). Therefore, we hypothesize that soil hygroscopic water content, whose determination is fast and technically less involved than particle-size analysis, positively correlates with clay percentage in both temperate and tropical soils and can provide a useful surrogate for soil clay content. Other research groups have presented results that emphasize the strong correlation between hygroscopic water and clay contents (Banin and Amiel, 1970; Petersen et al., 1996; Tuller and Or, 2005; Resurreccion et al., 2011); however, there is no specific water potential or relative humidity $(\mathrm{RH})$ agreed on at which these relationships should be determined.

Clay content and type of clay minerals determine the magnitude of the soil-specific surface area (Petersen et al., 1996). Banin and Amiel (1970) presented data with specific surface area showing a strong linear dependence $\left(r^{2}=0.902\right)$ to clay contents. In the studies of Banin and Amiel (1970) and Dirksen and Dasberg (1993), hygroscopic water content had a strong linear correlation $\left(r^{2}=0.936\right)$ with soil-specific surface area. Recently, Logsdon et al. (2010) determined hygroscopic water content of soils in a vapor-tight container over distilled water at $\sim 99 \% \mathrm{RH}$ and concluded that higher hygroscopic water content is associated with high soil-specific surface area. To come to an agreement about a specific RH level at which hygroscopic water content ought to be determined, in-depth knowledge of the water release characteristics of different clay minerals is required. Therefore, the objectives of the present study were to (i) determine the water release characteristics for standard source clays, (ii) define a suitable RH level for estimating clay content for the source clays, and (iii) examine the relationship between hygroscopic water content and clay content using the defined RH for soils with varying mineralogies from temperate and tropical regions.

\section{MATERIALS AND METHODS Clay Minerals}

Standard 100\% source clay minerals were used to determine the hygroscopic water content as a function of RH. The selected samples were the same as used by Lebron et al. (2009) and included Silver Hill illite from Montana (IMt-1) and Ca-montmorillonite from Cheto, AZ (SAz-1) obtained from the Clay Mineral Society's Source Clay Repository, Wyoming bentonite (Aqua Technologies of Wyoming, Casper), and kaolinite from the Lamar pit (Bath, SC). The SAz-1 montmorillonite was saturated with $\mathrm{Na}, \mathrm{Ca}$, or $\mathrm{Mg}$ to produce clay samples saturated with a single ion (Goldberg and Glaubig, 1987).

\section{Soil Samples}

The first set of samples contained tropical soils from the University of the West Indies soil sample collection in Trinidad. Trinidad is the southernmost of the islands of the Lesser Antilles in the Caribbean Sea and is situated $10^{\circ} 3^{\prime} \mathrm{N} 60^{\circ} 55^{\prime} \mathrm{W}$ and $10^{\circ} 50^{\prime} \mathrm{N} 61^{\circ} 55^{\prime} \mathrm{W}$. The 23 soils used for this study were collected from different locations across the island, representing a 
range of soil types including kaolinitic, micaceous, and montmorillonitic soils (Table 1). In addition, 20 temperate soils from the University of Arizona Department of Soil, Water and Environmental Sciences' source soil collection, again representing a wide range of mineralogies and clay content were analyzed (Table 1).

Furthermore, a number of datasets originating from both Trinidad and the United States that were previously used for EMI calibration were investigated. Soils from Trinidad were collected from Guayaguayare, Moruga, Centeno and Woodland from locations identified via an EMI-directed soil sampling method (Lesch et al., 2000). Data from the United States were obtained from the T.W. Daniel Experimental Forest in northern Utah and the Reynolds Mountain East catchment within the Reynolds Creek Experimental Watershed in southwestern Idaho (Abdu et al., 2008).

\section{Clay and Soil Sample Analysis}

The water release characteristics for the source clays were measured with a Dewpoint Potentiameter (WP4-T, Decagon Devices, Inc., Pullman, WA). The clay samples were oven-dried at $105^{\circ} \mathrm{C}$ and then left equilibrating with the ambient laboratory atmosphere at controlled temperature $\left(25^{\circ} \mathrm{C}\right)$ for several months. Once the humidity level of interest had been reached and was stable for 2 to $3 \mathrm{~d}$, samples were weighed with an analytical balance and the soil water potential was determined with the WP4-T. Relative humidity was measured using a humidity sensor (Thermo Hygro, Thermo-Fisher, Waltham, MA). To establish a range of humidities, this experiment lasted about $5 \mathrm{mo}$. Soil water potential was converted to RH via the well-known Kelvin equation:

$$
\psi_{w}=\frac{R T \rho_{\mathrm{w}}}{M_{\mathrm{w}}} \ln \left(\frac{e}{e_{0}}\right)
$$

where $\Psi_{\mathrm{w}}$ is soil water potential, $R$ is the universal gas constant (8.31 $\left.\mathrm{J} \mathrm{K}^{-1} \mathrm{~mol}^{-1}\right), T$ is the absolute temperature $\left({ }^{\circ} \mathrm{K}\right), \rho_{\mathrm{w}}$ is the density of water $\left(\mathrm{kg} \mathrm{m}^{-3}\right)$, and $M_{\mathrm{w}}$ is the molecular weight of water $\left(0.018 \mathrm{~kg} \mathrm{~mol}^{-1}\right)$. The ratio of $e$, the water vapor pressure, to $e_{0}$, the saturation vapor pressure, is the temperature-dependent $\mathrm{RH}$, which can be rewritten as

$$
\mathrm{RH}=\frac{e}{e_{0}}=\exp ^{\frac{M_{\mathrm{w}} \psi_{\mathrm{w}}}{\rho_{w} R T}} .
$$

The soil samples originating from Trinidad were first oven-dried at $105^{\circ} \mathrm{C}$ and then equilibrated with the ambient atmosphere of a temperature-controlled room $\left(25^{\circ} \mathrm{C}\right)$ with a monitored $\mathrm{RH}$
(Thermo Hygro, Thermo-Fisher, Waltham, MA) of 50\%. The steps developed to measure hygroscopic water content $\left(\theta_{\mathrm{hw}}\right)$ at $\mathrm{RH}^{50}$ are described below:

1. Weigh the sample containers using a four-decimal analytical balance (Wc).

2. Weigh approximately $10 \mathrm{~g}$ of air-dried sample into the sample containers and place them in the oven to dry at $105^{\circ} \mathrm{C}$ for $24 \mathrm{~h}$, weigh again directly from the oven before cooling using a thermal isolator to protect the balance (Woven-dry).

3. Allow the oven-dried samples to equilibrate to $\mathrm{RH}^{50}$ at ambient conditions in the laboratory. Equilibration of our samples was achieved within 48 to $72 \mathrm{~h}$ when $\mathrm{RH}$ was monitored using a thermohygrometer sensor.

4. Measure the humidity, monitor over a 2 -h period, if $50 \%$ is maintained reweigh the equilibrated samples to determine the moisture gain $\left(\mathrm{W}_{\mathrm{RH} 50}\right)$.

5. The $\theta_{\text {hw }}$ at $\mathrm{RH}^{50}$ in the sample is calculated gravimetrically as

$$
\theta_{\mathrm{hw}}=\frac{\left(W_{\mathrm{RH} 50}-W_{\mathrm{c}}\right)-\left(W_{\text {oven-dry }}-W_{\mathrm{c}}\right)}{\left(W_{\text {oven-dry }}-W_{\mathrm{c}}\right)}
$$




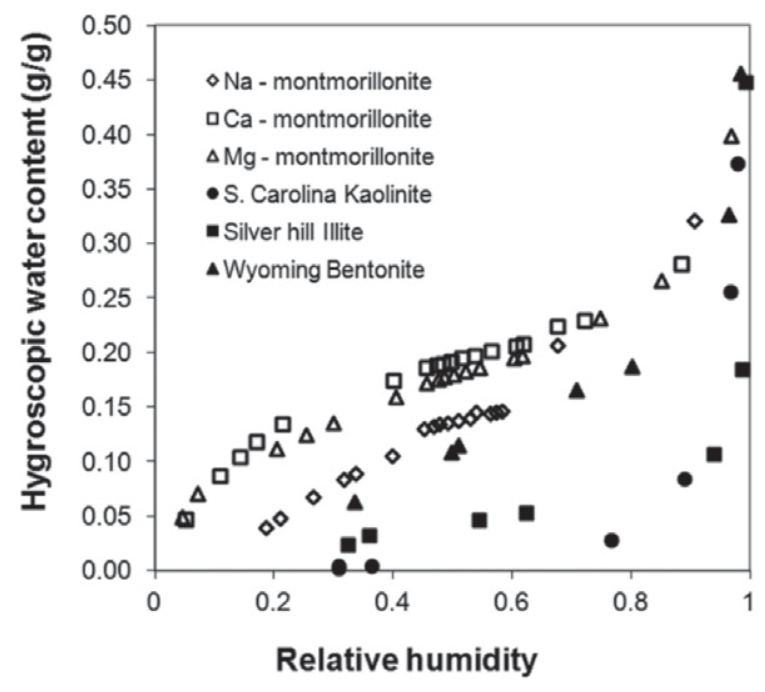

Fig. 1. Water release curves for standard clays.

The samples from Arizona were equilibrated at $50 \%$ humidity and $25^{\circ} \mathrm{C}$ using a temperature and humidity controlled environmental chamber $(1007 \mathrm{H}$ Temperature-Humidity Chamber, TestEquity, LLC, Moorpark, CA). An additional experiment was conducted to determine how fast soils reabsorb water following oven-drying. To achieve this, oven-dried soil samples were weighed and kept in the environmental chamber at $50 \% \mathrm{RH}$ and $25^{\circ} \mathrm{C}$. The soil samples were then weighed in 3-h intervals to capture the initially highly dynamic change in water content. The time interval was then stepwise increased to 6,12 , and $24 \mathrm{~h}$ for a total time period of $15 \mathrm{~d}$. The clay content was determined with the hydrometer method (Gee and Bauder, 1986). Organic matter was removed using hydrogen peroxide $\left(35 \% \mathrm{H}_{2} \mathrm{O}_{2}\right)$ and dispersed using $5 \%$ sodium hexametaphosphate.

\section{RESULTS}

\section{Source Clay Samples}

Results for hygroscopic water content $\left(\theta_{\mathrm{hw}}\right)$ as a function of $\mathrm{RH}$ are presented in Fig. 1. The data for 2:1 clay minerals show a substantial increase in $\theta_{\mathrm{hw}}$ at low humidities, a leveling off at RH values between about 50 to $60 \%$ and then increasing water content again at $\mathrm{RH}$ values above $80 \%$. Both the $2: 1$ clays montmorillonite and illite adsorbed more than $0.05 \mathrm{~m}^{3}$ of water per gram of oven-dry soil at RH values of $~ 50 \%$. However, kaolinite did not adsorb water until $\sim 80 \%$ humidity or higher.

\section{Determination of Hygroscopic Water Content at $50 \%$ Relative Humidity}

On the basis of results from the water release curves (Fig. 1 ), we adopted the $\mathrm{RH}^{50}$ for equilibrating our soils as a compromise value considering the range of mineralogies. This also represents a relatively stable point at which the change of $\theta_{\mathrm{hw}}$ with humidity is at a minimum; $\mathrm{RH}^{50}$ is also commonly attained in the laboratory meaning no special equipment is required to equilibrate the soils at this humidity.

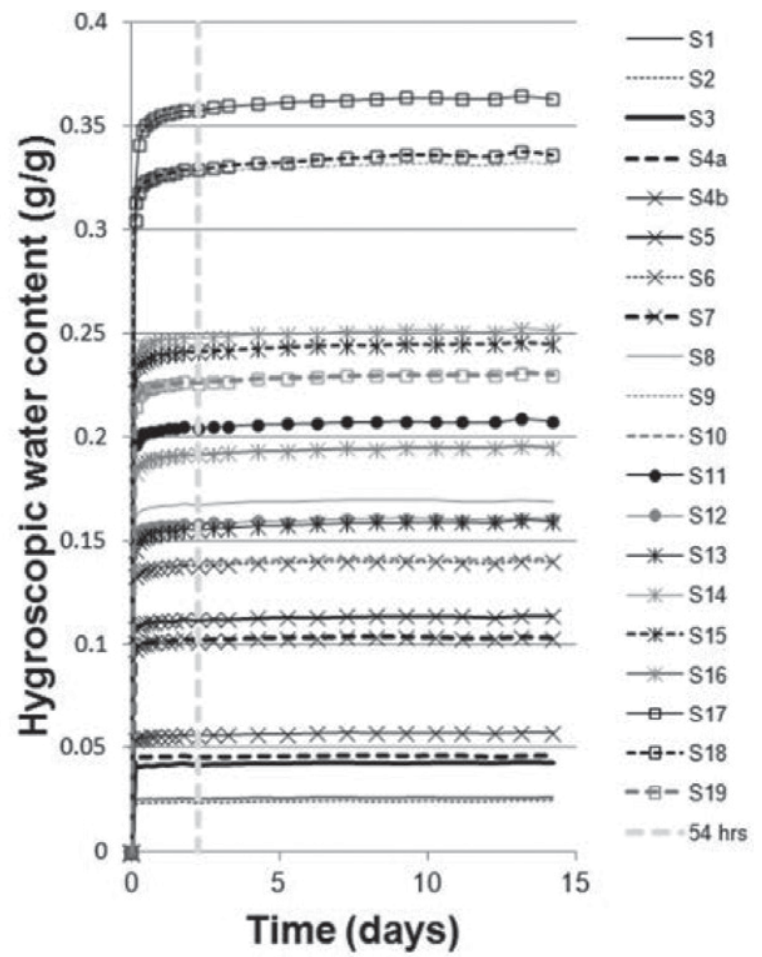

Fig. 2. Water uptake on treated temperate Arizona soils at $25^{\circ} \mathrm{C}$ indicating water is rapidly adsorbed in $\mathbf{4 8} \mathrm{h}$.

\section{Water Uptake and Equilibration of Samples at $\mathbf{5 0} \%$ Relative Humidity}

After adopting the $\mathrm{RH}^{50}$ for equilibrating our soils, we determined the time for samples to reabsorb water in the lab following oven-drying. The results of the rate at which water uptake occur using the Arizona soils data set after oven-drying is presented in Fig. 2. The facilities at the laboratory in Arizona allowed samples to be analyzed in greater detail under more tightly controlled conditions. In our experimental method soils are oven-dried and then allowed to re-equilibrate at $\mathrm{RH}^{50}$ to determine the fraction of hygroscopic water. The samples tend to equilibrate within $\sim 2 \mathrm{~d}$ (Fig. 2). We suggest leaving the samples for a minimum of $54 \mathrm{~h}$, which seems appropriate for reequilibration. This is convenient for laboratory scheduling, as soils may be removed from a drying oven, after drying overnight, and then be weighed with the start of equilibration at $\sim 0900$ h. Samples can be left to equilibrate for $2 \mathrm{~d}$ and then measured around $1500 \mathrm{~h}$ or later to determine the water uptake.

\section{Effect of Organic Matter Removal on Water Adsorption at $\mathbf{5 0} \%$ Relative Humidity}

Hygroscopic water content as a function of the clay percentage of untreated and treated Arizona soils that have had organic matter removed are presented in Fig. 3. The purpose of this was to determine if the presence of organic matter strongly affected the relationship between the hygroscopic water content and clay percentage. The removal of organic matter results in slightly lower water adsorption, confirming that the clay percentage is the major factor in determining the amount of water adsorbed. On the basis of the regression lines shown, and assuming that the organic mat- 


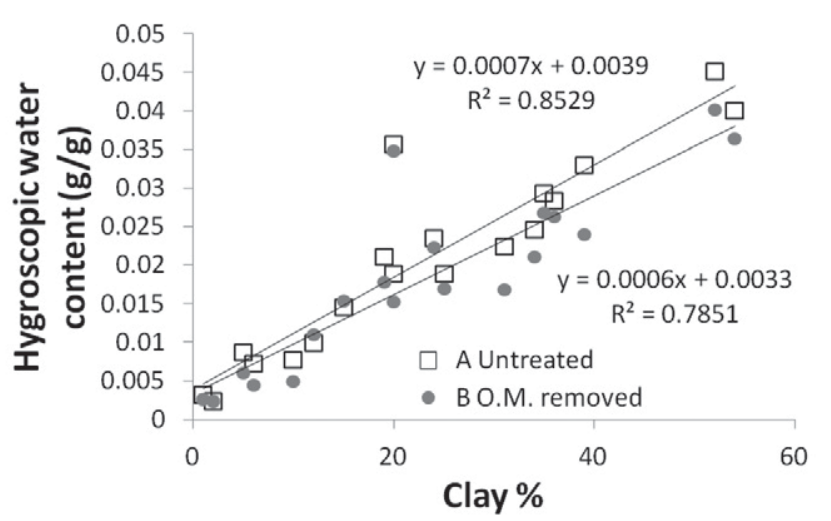

Fig. 3. Hygroscopic water content as a function of the clay percentage comparing untreated and treated temperate Arizona soils that have had organic matter (O.M.) removed.

ter is largely responsible for any additional water adsorption, 5\% difference in organic matter for a soil with $\sim 50 \%$ clay may result in an $8 \%$ difference in the estimated clay percentage, which is acceptable for using field soil for a reconnaissance survey. This indicates that for these soils, organic matter was not a major issue, but in future work we might want to examine how different types of organic matter adsorb water and whether the relationship is linear.

Figure 4 compares the measurement error associated with determining the hygroscopic water content of soil samples based on mass gained, with the measurement error associated with determining clay content from sedimentation analysis using the hydrometer method. As expected, the measurement errors are generally smaller at higher clay contents, with the percentage error increasing rapidly at low clay contents. The error for the hygroscopic water content is generally lower at low clay contents because our ability to weigh accurately is greater than our ability to detect clay via sedimentation at low clay contents; from clay contents of 10 to $50 \%$ the errors involved are similar. This indicates that the greatest errors in estimating clay percentage from hygroscopic water will be dependent on the spatial variability of organic matter, if not removed from samples.

\section{Hygroscopic Water Content as a Function of Clay Content for Soils Equilibrated at $\mathbf{5 0 \%}$ Relative Humidity}

Hygroscopic water content as a function of clay percentage for both the Arizona and Trinidad soil data sets equilibrated at $\mathrm{RH}^{50}$ is presented in Fig. 5. The Trinidad soils are divided according to major mineralogy, kaolinitic, micaceous and mixed clays, sesquioxides, and montmorillonitic; the Arizona soils were dominated by mica and illite clay minerals. These soils represent the range of 2:1 and 1:1 clay mineralogies (Table 1) and indicate strong consistency in response compared to the trend lines indicated for the different pure clay minerals. The soils dominated by sesquioxides and montmorillonite have distinctively higher hygroscopic water content values than the other soils. The montmorillonite follows the bentonite trend line, while the micaceous and mixed mineralogy follows the illite trend line. Noticeably the oxide-dominated soil follows the bentonite trend line indicating this soil can adsorb a lot of water; highly weathered tropical soils with amorphous oxides

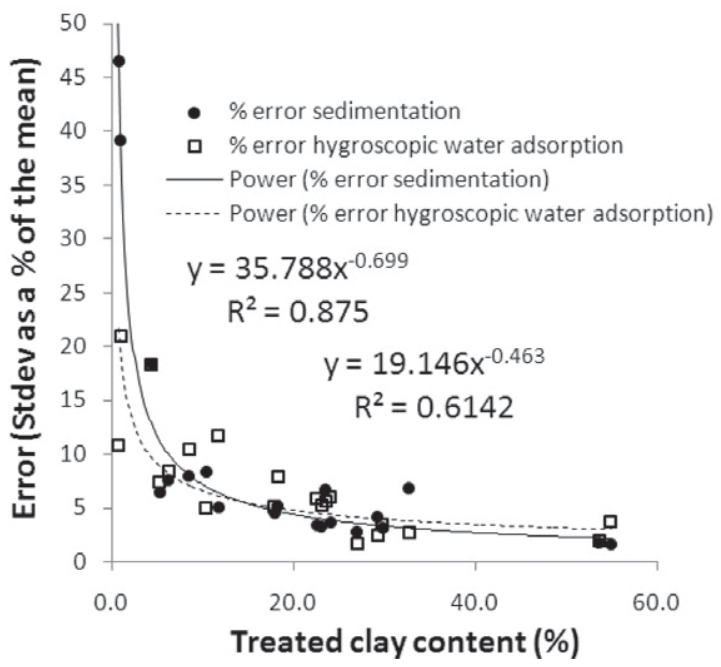

Fig. 4. Trinidad and Arizona soils error as a function of the treated (organic matter removed) clay percentage; the error is represented as the standard deviation (SD) as a percentage of the mean of four independent replicates.

can have large surface areas on which water can adsorb (Sanchez, 1976; Goldberg et al., 2001; Robinson et al., 2009b). In addition, some of the kaolinitic soils (clay content 50-70\%) have higher water content than might be expected. This may occur because of the presence of oxides in these soils; biasing values upward and requires further research. The $r^{2}$ values for the regression equations of hygroscopic water content as a function of clay content were 0.78 and 0.68 for Arizona soils and all Trinidad soils, respectively. This indicates a positive linear relationship between hygroscopic water content and clay content for soils of varying mineralogies from temperate and tropical regions. The relationship was only superior in the Arizona soils compared to the Trinidad soils because of less mineralogical variation. The $r^{2}$ for the Trinidad soils increased to 0.84 after removing the oxide and montmorillonite soils.

A compilation of available data sets that contain both clay percentage information and hygroscopic water content $\left(\mathrm{RH}^{50}\right)$ for samples taken from landscapes mapped with the EMI sensor in the United States and Trinidad are presented in Fig. 6. The results fall broadly in the same location as in Fig. 5. The $r^{2}$ values

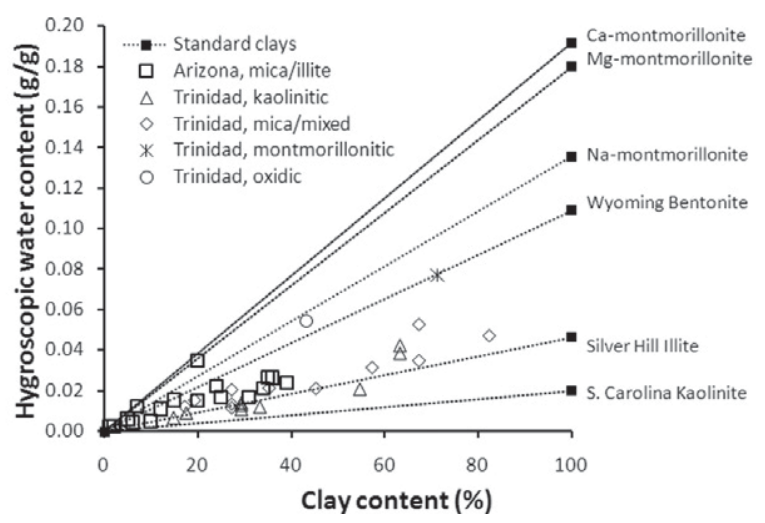

Fig. 5. Hygroscopic water content $\left(\mathrm{RH}^{50}\right)$ as a function of clay percentage for 23 tropical Trinidad soils divided by major mineralogy, 20 temperate Arizona soils, and $100 \%$ clay samples. The dashed linear trend lines join the $100 \%$ clay samples to the origin as a guide for comparison with Fig. 6. 


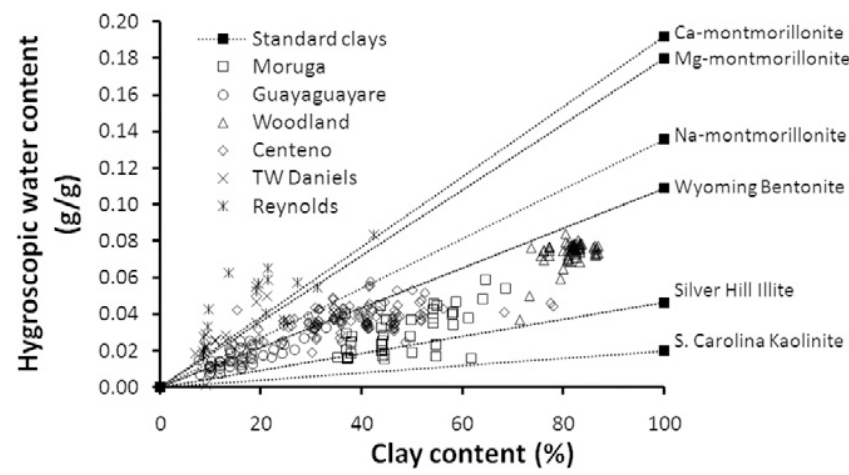

Fig. 6. Six data sets showing field-scale variability; two data set from soils dominated by Ca montmorillonite from Utah and four from Trinidad. The dashed linear trend lines join the $100 \%$ clay samples to the origin as a guide for comparison with Fig. 5. For $r^{2}$ and RMSE see Table 2.

with intercept set to zero, RMSE and corresponding mineralogy are presented in Table 2. The $r^{2}$ values improve as the range of the clay percentage broadens. All RMSE values for clay percentage as a function of $\mathrm{RH}^{50}$ fall below $10 \%$ with the median value being $5 \%$. This indicates that for these soils, $\mathrm{RH}^{50}$ was a reasonable predictor of clay percentage. Placing a regression line through all data (clay $\%=1037.5^{*} \mathrm{RH}^{50}$ ) gave an $r^{2}$ of 0.70 and resulted in a RMSE of $6.5 \%$ which may be acceptable for reconnaissance survey. However, we do not advocate the use of a single relationship as it is mineralogy dependent. In this regard a site-specific calibration should be established between $\mathrm{RH}^{50}$ and clay percentage that could then be used to estimate clay percentage from subsequent samples measured only for $\mathrm{RH}^{50}$. $\mathrm{RH}^{50}$ values would be useful for providing secondary data in, for example, co-kriging geostatistical methods (Lesch et al., 1995a). The results indicate reasonable correlations, demonstrating that hygroscopic water content at $\mathrm{RH}^{50}$ has good potential to act as a pedotransfer function to estimate clay percentage at least for reconnaissance surveys and as a secondary variable for geostatistical interpolation.

\section{DISCUSSION}

Developing a standard approach to estimating clay percentage from the hygroscopic water content relies on agreeing on an accepted $\mathrm{RH}$ value at which to measure the hygroscopic water content. Different authors have used different values, Banin and Amiel (1970) used air-dry samples, while Petersen et al. (1996) used a pressure of 1.5 MPa. Logsdon et al. (2010) determined hygroscopic water content of air-dry soils in a vapor-tight container over distilled water at $~ 99 \%$ RH. In an effort to standardize a method,

Table 2. Root mean square error for the prediction of clay percentage from the relative humidity at $50 \%\left(\mathrm{RH}^{50}\right)$ values for a selection of soils and the dominant mineralogy.

\begin{tabular}{llcc}
\multicolumn{1}{c}{ Soil sampling location } & $\begin{array}{c}\boldsymbol{r}^{\mathbf{2}} \text { (No. of } \\
\text { samples) }\end{array}$ & $\begin{array}{c}\text { Clay \% } \\
\text { RMSE }\end{array}$ & $\begin{array}{c}\text { Dominant } \\
\text { mineralogy }\end{array}$ \\
\hline Moruga, Trinidad & $0.40(40)$ & 6.6 & Mixed \\
Guayaguayare, Trinidad & $0.62(46)$ & 4.0 & Kaolinitic \\
Woodland, Trinidad & $0.40(67)$ & 9.0 & Montmorillonitic \\
Centeno, Trinidad & $0.87(123)$ & 6.2 & Mixed \\
TW Daniels, Utah & $0.63(15)$ & 3.5 & Montmorillonitic \\
Reynolds Creek, Idaho & $0.48(17)$ & 4.2 & Montmorillonitic \\
\hline
\end{tabular}

Lebron et al. (2009), used a hygroscopic water content of $41 \%$ to determine gypsum content in soils. They used $41 \%$ because this is the $\mathrm{RH}$ achieved by equilibrating samples over a saturated solution of $\mathrm{K}_{2} \mathrm{CO}_{3}$ in a dessicator, which makes standardization easier, especially given the temperature stability of the $\mathrm{RH}$ of $\mathrm{K}_{2} \mathrm{CO}_{3}$. However, finding a salt that offers a temperature stable $\mathrm{RH}$ at $\sim 50$ to $60 \%$ is not straightforward. Any chosen value of RH is a tradeoff between having a zone of minimal relative change of slope of the water release curve of the soil (Fig. 1) and having enough water to obtain a meaningful measurement of hygroscopic water content. $\mathrm{RH}^{50}$ was chosen as a compromise, bearing in mind this trade-off, which seems to work reasonably well even in kaolinitic soils. The use of $\mathrm{K}_{2} \mathrm{CO}_{3}$ is appealing and good for 2:1 clay mineral soils but is not so good for kaolinitic soils which have essentially desorbed all their water at $\mathrm{RH} 41 \%$.

The benefits of proximal sensing techniques in reconnaissance surveys have, to some extent, been undermined by the cost and tedious requirements for soil sampling and analysis of properties such as clay percentage required for their calibration. The removal of organic matter from the samples in the current study resulted in only minimal reduction in adsorbed water (Fig. 4). This signifies that in soils low in organic matter, clay percentage is the major factor in determining the amount of water adsorbed. Clay percentage has been shown by previous works to be strongly correlated with specific surface area and hygroscopic water content (e.g., Banin and Amiel, 1970; Petersen et al., 1996; Robinson et al., 2002). However, hygroscopic water content which is a quicker and cheaper soil property to measure is often not routinely collected by soil surveys (Robinson et al., 2002). Since the amount of water adsorbed by a sample varies depending on the ambient humidity, finding a suitable $\mathrm{RH}$ for the equilibration of soils is important for the determination of hygroscopic water content to speed up the interpretation of geophysical signals. In our study, $\mathrm{RH}^{50}$ was chosen as a compromise value from the determination of hygroscopic water content for standard clays which generally yielded hygroscopic water content values that were strongly correlated with clay percentage for both tropical and temperate soils of varying mineralogies.

\section{SUMMARY AND CONCLUSIONS}

The work presented describes a simple, cost and time efficient method of estimating clay content using hygroscopic water content measurements. To successfully determine the relationship between hygroscopic water content and clay content, it is important to identify a suitable value of $\mathrm{RH}$ for equilibration of soils. On the basis of our results on water release curves of standard clay minerals, this value was identified to be $\sim 50 \%$, a relatively stable point at which the change in hygroscopic water content with humidity is at a minimum. This value was then used to equilibrate soil samples from tropical (Trinidad) and temperate (Arizona) regions exhibiting a wide range of soil mineralogy.

The work presented indicates positive correlations between soil hygroscopic water content measured at $\mathrm{RH}^{50}$ and the clay percentage in the soil. Hygroscopic water content measured at 
$\mathrm{RH}^{50}$ has good potential to act as a pedotransfer function to estimate clay percentage for surveys. One of three approaches, with increasing accuracy, could be adopted:

1. Estimate clay percentage from the linear hygroscopic water content calibration presented for all soils.

2. Perform a site-specific calibration on a soil subsample between clay and $\mathrm{RH}$.

3. Perform a full calibration using particle size analysis.

With the growth of proximal sensing the first approach offers a cheap and rapid way to estimate the dependence of soil geophysical signal response surfaces to hygroscopic water content as a surrogate for soil clay percentage for reconnaissance survey. This may guide a surveyor as to the major soil parameter contributing to the geophysical signal response.

\section{REFERENCES}

Abdu, H., D.A. Robinson, M. Seyfried, and S.B. Jones. 2008. Geophysical imaging of watershed subsurface patterns and prediction of soil texture and water holding capacity. Water Resour. Res. 44:W00D18. doi:10.1029/2008WR007043.

Banin, A., and A. Amiel. 1970. A correlative study of the chemical and physical properties of a group of natural soils of Israel. Geoderma 3:185-198. doi:10.1016/0016-7061(70)90018-2.

Briggs, L.J., and H.L. Shantz. 1912. The wilting coefficient and its indirect determination. Bot. Gaz. 53:20-37. doi:10.1086/330708.

Crave, A., and C. Gascuel-Odoux. 1997. The influence of topography on time and space distribution of soil surface water content. Hydrol. Processes 11:203-210. doi:10.1002/(SICI)1099-1085(199702)11:2<203::AIDHYP432>3.0.CO;2-K.

Dirksen, C., and S. Dasberg. 1993. Improved calibration of time domain reflectometry soil water content measurements. Soil Sci. Soc. Am. J. 57:660-667. doi:10.2136/sssaj1993.03615995005700030005x.

Doolittle, J.A., K.A. Sudduth, N.R. Kitchen, and S.J. Indorante. 1994. Estimating depths to claypans using electromagnetic induction methods. J. Soil Water Conserv. 49:572-575.

Friedman, S.P., 2005. Soil properties influencing apparent electrical conductivity: A review. Comput. Electron. Agric. 46:45-70. doi:10.1016/j.compag.2004.11.001.

Gee, G.W., and J.W. Bauder. 1986. Particle-size analysis. In: A. Klute, editor, Methods of soil analysis. Part 1.2nd ed. Agron. Monogr. 9. ASA and SSSA, Madison, WI. p. 383-411.

Goldberg, S., and R.A. Glaubig. 1987. Effect of saturating cation, pH, and aluminum and iron oxide on the flocculation of kaolinite and montmorillonite. Clays Clay Miner. 35:220-227. doi:10.1346/CCMN.1987.0350308.

Goldberg, S., I. Lebron, D.L. Suarez, and Z.R. Hinedi. 2001. Surface characterization of amorphous aluminum oxides. Soil Sci. Soc. Am. J. 65:78-86. doi:10.2136/sssaj2001.65178x.

Grayson, R., and G. Blöschl. 2000. Spatial patterns in catchment hydrology: Observations and modeling. Cambridge Univ. Press, Cambridge, UK.

Harvey, O.R., and C.L.S. Morgan. 2009. Predicting regional-scale soil variability using a single calibrated apparent soil electrical conductivity model. Soil Sci. Soc. Am. J. 73:164-169. doi:10.2136/sssaj2008.0074.

Lebron, I., J. Herrero, and D.A. Robinson. 2009. Determination of gypsum content in soils exploiting the gypsum-bassanite phase change. Soil Sci. Soc. Am. J. 73:403-411. doi:10.2136/sssaj2008.0001.

Lesch, S.M., D.J. Strauss, and J.D. Rhoades. 1995a. Spatial prediction of soil salinity using electromagnetic induction techniques: 1 . Statistical prediction modelsA comparison of multiple linear regression and cokriging. Water Resour. Res. 31:373-386. doi:10.1029/94WR02179.

Lesch, S.M., D.J. Strauss, and J.D. Rhoades. 1995b. Spatial prediction of soil salinity using electromagnetic induction techniques: 2 . An efficient spatial sampling algorithm suitable for multiple linear regression model identification and estimation. Water Resour. Res. 31:387-398. doi:10.1029/94WR02180.
Lesch, S.M., J.D. Rhoades, and D.L. Corwin. 2000. ESAP-95 Version 2.01R: User 17 manual and tutorial guide. Res. Rep. No. 146, June 2000. USDA-ARS George E. Brown Jr. Salinity Lab., 18. Riverside, CA.

Logsdon, S., T.R. Green, M. Seyfried, S.R. Evett, and J. Bonta. 2010. Hydra probe and twelve-wire probe comparisons in fluids and soil cores. Soil Sci. Soc. Am. J. 74:5-12. doi:10.2136/sssaj2009.0189.

Petersen, L.W., P. Moldrup, O.H. Jacobsen, and D. Rolston. 1996. Relations between specific surface area and soil physical and chemical properties. Soil Sci. 161:9-21. doi:10.1097/00010694-199601000-00003.

Quirk, J.P., and R.S. Murray. 1999. Appraisal of the ethylene glycol monoethyl ether method for measuring hydratable surface area of clays and soils. Soil Sci. Soc. Am. J. 63:839-849. doi:10.2136/sssaj1999.634839x.

Rawlins, B.G., R.M. Lark, and R. Webster. 2007. Understanding airborne radiometric survey signals across part of eastern England. Earth Surf. Processes Landforms 32:1503-1515. doi:10.1002/esp.1468.

Resurreccion, A.C., P. Moldrup, M. Tuller, T.P.A. Ferre, K. Kawamoto, T. Komatsu, and L.W. de Jonge. 2011. Relationship between specific surface area and the dry end of the water retention curve for soils with varying clay and organic carbon contents. Water Resour. Res. 47:W06522. doi:10.1029/2010WR010229.

Robinson, D.A., J.D. Cooper, and C.M.K. Gardner. 2002. Modelling the relative permittivity of soils using soil hygroscopic water content. J. Hydrol. 255:39-49. doi:10.1016/S0022-1694(01)00508-X.

Robinson, D.A., C.S. Campbell, J.W. Hopmans, B.K. Hornbuckle, S.B. Jones, R. Knight, F. Ogden, J. Selker, and O. Wendroth. 2008a. Soil moisture measurement for ecological and hydrological watershed scale observatories: A review. Vadose Zone J. 7:358-389. doi:10.2136/vzj2007.0143.

Robinson, D.A., A. Binley, N. Crook, F.D. Day-Lewis, T.P.A. Ferre, V.J.S. Grauch R. Knight, M. Knoll, V. Lakshmi, R. Miller, J. Nyquist, L. Pellerin, K. Singha, and L. Slater. 2008b. Advancing process-based watershed hydrological research using near-surface geophysics: A vision for, and review of, electrical and magnetic geophysical methods. Hydrol. Processes 22:3604-3635. doi:10.1002/ hyp.6963.

Robinson, D.A., L. Lebron, and H. Vereecken. 2009a. On the definition of the natural capital of soils: A framework for description, evaluation, and monitoring. Soil Sci. Soc. Am. J. 73:1904-1911. doi:10.2136/sssaj2008.0332.

Robinson, D.A., S.B. Jones, J.M. Blonquist, R. Heinse, I. Lebron, and T.E. Doyle. 2009b. The dielectric response of the tropical Hawaiian Mars soil simulant JSC Mars-1. Soil Sci. Soc. Am. J. 73:1113-1118. doi:10.2136/sssaj2008.0297.

Samouelian, A., I. Cousin, A. Tabbagh, A. Bruand, and G. Richard. 2005. Electrical resistivity survey in soil science: A review. Soil Tillage Res. 83:173-193. doi:10.1016/j.still.2004.10.004.

Sanchez, P.A. 1976. Properties and management of soils in the tropics. John Wiley $\&$ Sons, New York.

Schaap, M.G., F.J. Leij, and M.Th. van Genuchten. 2001. ROSETTA: A computer program for estimating soil hydraulic parameters with hierarchical pedotransfer functions. J. Hydrol. 251:163-176. doi:10.1016/S0022-1694(01)00466-8.

Slater, L., D. Ntarlagiannis, and D. Wishart. 2006. On the relationship between induced polarization and surface area in metal-sand and clay-sand mixtures. Geophysics 71:A1-A5.

Schjonning, P., I.K. Thomsen, P. Moldrup, and B.T. Christensen. 2003. Linking soil microbial activity to water- and air-phase contents and diffusivities. Soil Sci. Soc. Am. J. 67:156-165. doi:10.2136/sssaj2003.0156.

Sudduth, K.A., N.R. Kitchen, W.J. Wiebold, W.D. Batchelor, G.A. Bollero, D.G. Bullock, D.E. Clay, H.L. Palm, F.J. Pierce, R.T. Schuler, and K.D. Thelen. 2005. Relating apparent electrical conductivity to soil properties across the northcentral USA. Comput. Electron. Agric. 46:263-283. doi:10.1016/j.compag.2004.11.010.

Taylor, M.J., K. Smettem, G. Pracilio, and W. Verboom. 2002. Relationships between soil properties and high-resolution radiometrics, central eastern Wheatbelt, Western Australia. Explor. Geophys. 33:95-102. doi:10.1071/EG02095.

Triantafilis, J., I.A. Huckel, and I.O.A. Odeh. 2001. Comparison of statistical prediction methods for estimating field-scale clay content using different combinations of ancillary variables. Soil Sci. 166:415-427. doi:10.1097/00010694200106000-00007.

Triantafilis, J., and S.M. Lesch. 2005. Mapping clay content variation using electromagnetic induction techniques. Comput. Electron. Agric. 46:203-237. doi:10.1016/j.compag.2004.11.006.

Tuller, M., and D. Or. 2005. Water films and scaling of soil characteristic curves at low water contents. Water Resour. Res. 41:W09403. doi:10.1029/2005WR004142. 
Reproduced with permission of the copyright owner. Further reproduction prohibited without permission. 